\title{
Rozwój przedsiębiorczości społecznej - istota i kierunki analizy
}

\author{
Agnieszka Pacut*
}

Streszczenie: Tło rozważań: Przedmiotem rozważań w artykule jest zagadnienie rozwoju przedsiębiorczości społecznej. Składa się ono z dwóch zakresowo nieostrych i treściowo wieloznacznych terminów. Z jednej strony przedsiębiorczość społeczna jest młodą, wymagającą poznania dziedziną badań, która wzbudza międzynarodowe zainteresowanie różnych środowisk od końca XX wieku. Z drugiej zaś strony, rozwój jest kategorią zakorzenioną w tradycji badań społecznych oraz debacie publicznej.

Cele: Celem artykułu jest systematyzacja wiedzy na temat znaczenia obu wskazanych powyżej pojęć oraz przedstawienie wybranych sposobów analizy zagadnienia opisanego jako rozwój przedsiębiorczości społecznej.

Metody: Do realizacji celu wykorzystano metodę analizy i syntezy literatury przedmiotu.

Wyniki: W świetle przeglądu literatury analiza rozwoju przedsiębiorczości społecznej może dotyczyć przedmiotu, uwarunkowań, procesu i wyników.

Konkluzje: Podjęte dotychczas w Polsce prace badawcze świadczą o wzroście zainteresowania i uznania dla niniejszego zagadnienia. Jednocześnie nasuwa się wniosek o konieczności rozwijania w kraju, we wskazanych obszarach, prac o charakterze empirycznym i teoretycznym z wykorzystaniem dorobku nauk ekonomicznych, społecznych i prawnych.

Słowa kluczowe: przedsiębiorczość społeczna, rozwój, przedmiot i zakres analizy.

\section{Wprowadzenie}

Przedmiotem rozważań w artykule uczyniono zagadnienie rozwoju przedsiębiorczości społecznej. Takie ujęcie tematu powoduje, iż analiza będzie dotyczyła nowego pojęcia w teorii, badaniach społecznych oraz debacie publicznej tj. przedsiębiorczości społecznej (ang. social entrepreneurship, niem. soziale Unternehmung, fr. l'entrepreneurial social). W najprostszym ujęciu termin ten oznacza działania przedsiębiorcze podejmowane dla osiągnięcia celu społecznego. Inicjatywy tego typu poszukują i oferują innowacyjnych rozwiązań problemów społecznych, stawiając wartość społeczną w centrum działalności podejmowanej przez osoby, grupy obywateli, organizacje. Innymi słowy, chodzi o rozwiązywanie problemów społecznych w duchu przedsiębiorczości, innowacyjności, ryzyka z wykorzystaniem zasad i rozwiązań rynko- wych. Z uwagi na społeczny cel, misję tego typu aktywności określa się mianem przedsiębiorczości nierynkowej (non-market entrepreneurship) [Shockley i in., 2008] lub/i przedsiębiorczości pozaekonomicznej [Kraśnicka, 2002]. Powstanie i rozwój tej formy aktywności w społeczeństwie wzbudza zainteresowanie środowiska akademickiego, które wskazuje na przedparadygmatowy etap jego rozwoju [Nicholls, 2013]. W literaturze przedmiotu pisze się o instytucjonalizacji przedsiębiorczości społecznej, przywołując takie jej przejawy jak [Sassmannshausen, Volkman, 2013]: powstawanie czasopism naukowych

\footnotetext{
* Agnieszka Pacut

Katedra Gospodarki i Administracji Publicznej Uniwersytet Ekonomiczny w Krakowie ul. Rakowicka 27, 31-510 Kraków e-mail: agnieszka.pacut@uek.krakow.pl
} 
dedykowanych wprost tej tematyce ${ }^{1}$, włączenie tej problematyki przez wiodące czasopisma w formie artykułów i dodatków tematycznych ${ }^{2}$, publikowanie monografii oraz serii wydawniczych [np. Mair i in., 2006; Lumpkin, Katz, 2011], a także powstawanie centrów propagujących praktyczną wiedzę na temat przedsiębiorczości społecznej oraz jednostek akademickich specjalizujących się naukowo w tej tematyce. Jednocześnie zagadnienie to stanowi przedmiot zainteresowania instytucji publicznych [np.: Głąbicka, 2011, s. 85108; Komisja Europejska, 2014; OECD, 1999]. Wspomniany problem od kilku lat zyskuje na znaczeniu również w Polsce, jednocześnie wymaga poznania i wyjaśnienia ${ }^{3}$.

Przedmiotem zainteresowania w ramach niniejszego artykułu uczyniono również rozwój - pojęcie zakorzenione w tradycji badań społecznych, wykorzystywane do wyjaśnienia różnorodnych fragmentów rzeczywistości [Chomątowski, 1986, s. 8]. Rozwój jest zjawiskiem powszechnym, naturalną cechą wszystkich obiektów stanowiących przedmiot zainteresowania człowieka [Januszkiewicz, 2011]. Równocześnie, jak zauważył J. Machaczka, termin ten należy do najbardziej oczywistych elementów naszego doświadczenia, choć nie zawsze potrafimy go właściwie interpretować [Machaczka, 1998, s. 13].

Powyższa uwaga wynika z faktu, iż jest to pojęcie nieostre i wieloznaczne. Ze względu na swoją złożoność termin ten jest stosunkowo rzadko używany bez określenia sfery, do której się odnosi [Masłyk, 1985, s. 15]. Często pojawia się w różnorodnych zestawie-

\footnotetext{
Np. „Journal of Social Entrepreneurship”, „Social Enterprise Journal", „International Journal of Social Entrepreneurship and Innovation".

2 Np. „Entrepreneurship Theory \& Practice”, ,J Journal of Business Venturing".

3 Liczba artykułów i opracowań literalnie poświęconych tej problematyce jest w dalszym ciągu niewielka. Niniejszą uwagę sformułowano analizując opracowania dostępne w bazach Bazekon Uniwersytetu Ekonomicznego w Krakowie oraz Katalogu Zbiorów Polskich Bibliotek Naukowych NUKAT.
}

niach - z przymiotnikiem (np. rozwój gospodarczy, rozwój lokalny) lub przedrostkiem (np. ekorozwój, samorozwój) [Borys, 2005], a także rzeczownikiem (np. polityka rozwoju). Owe związki, kolokacje, są silnie zespolone znaczeniowo i determinują interpretację oraz zakres analizy. Dlatego w literaturze przedmiotu wspomina się o "nadbogactwie” znaczenia pojęcia „rozwój” [Masłyk, 1985, s. 14] lub wprost twierdzi, że "definicja pojęcia rozwoju jest zmienna od nauki do nauki, a nierzadko angażuje też pewne stanowiska wartościujące" [Nowak, 2011, s. 259]. Wspomniany termin jest ostatnio chętnie wykorzystywany w debacie publicznej dotyczącej rozwiązywania problemów społecznych. Nierzadko nie jest on w ogóle definiowany; często przyjmuje się jego potoczne rozumienie, używa swobodnie, abstrahując od jego istoty i zakresu.

Ze względu na powyższe uzasadnienia podjęto próbę przeanalizowania podstawowych znaczeń terminu rozwój, określenia sposobów jego interpretacji oraz wykorzystania na potrzeby analizy przedsiębiorczości społecznej. Celem artykułu jest systematyzacja wiedzy na temat znaczenia obu wskazanych powyżej pojęć oraz przedstawienie wybranych sposobów analizy zagadnienia opisanego jako rozwój przedsiębiorczości społecznej.

Artykuł powstał na podstawie analizy i syntezy literatury przedmiotu. Pojęcie rozwoju omówiono wykorzystując piśmiennictwo krajowe, które podejmuje i wyjaśnia wspomniany termin. Z kolei istotę przedsiębiorczości społecznej przedstawiono wykorzystując najczęściej cytowane - według Google Scholar i Publish or Perish - zagraniczne publikacje na ten temat oraz dodatkowo opracowania o charakterze przekrojowym i bibliometrycznym.

Artykuł ma charakter teoretyczny - uzupełnienia on dotychczasowe analizy na temat rozwoju przedsiębiorczości społecznej, 
porządkując potencjalne kierunki badań w tym obszarze.

\section{Przedsiębiorczość społeczna - konceptualizacja}

Termin przedsiębiorczość społeczna pojawił się w literaturze przedmiotu w latach 90 . XX wieku [Brock, Kim, 2011]. Akademicy doszukują się jego źródeł w pracach takich autorów jak: J. Banks, A. Etzioni, N. Chambarlain [Nicholls, 2006, s. 7], czy też w opracowaniach D.R. Younga istotnych dla konceptualizacji tego terminu w Stanach Zjednoczonych [Bacq, Janssen, 2011, s. 375]. Przedsiębiorczość społeczna jest opisana w literaturze przedmiotu za pomocą wielu różnych terminów. Anglojęzyczne piśmiennictwo dostarcza odmiennych określeń na opisanie inicjatyw z tego zakresu. Do wyrażenia tej samej idei używa się takich określeń jak: social entrepreneurship, social entrepreneurship organization, social entrepreneur. W literaturze funkcjonują także inne terminy tj.: sustainable entrepreneurship, innovative social purpose business enterprises, social business, community enterprise, sustainable enterprise, indigenous enterprise, community-based entrepreneurship, the fair trade movement.

Przedsiębiorczość społeczna nie posiada powszechnie akceptowanej definicji. W literaturze funkcjonują różne nurty, wskazujące na jej złożony charakter oraz wielopłaszczyznowość. Wykorzystując wyniki badań i analiz poświęconych koncepcji przedsiębiorczości społecznej opublikowane w anglojęzycznych czasopismach i podręcznikach oraz analizując najczęściej cytowane definicje terminu z wykorzystaniem Google Scholar i Publih or Perish można wyróżnić kilka podejść do niniejszego zagadnienia.

Po pierwsze, można wskazać na podmiotowe, przedmiotowe i procesowe ujęcie terminu [Brouard, Larivet, 2010, s. 4052; Mair, Marti, 2004, s. 3-4; Bacq, Janssen,
2011, s. 375; Dancin i in., 2010, s. 37-57; Granados i in., 2011]. Sedno opisu przedsiębiorczości społecznej w ujęciu podmiotowym stanowi przedsiębiorca społeczny - postrzegany jako wizjonerska jednostka zdolna do identyfikacji i wykorzystania okazji dla realizacji misji społecznej i znalezienia innowacyjnych rozwiązań problemów społecznych wspólnoty [Hoogendoorn i in., 2010, s. 1-43]. Pełni on funkcję agenta zmiany w sektorze społecznym, który poszukuje systemowych zmian i trwałych ulepszeń [Dees, 2008].

W ujęciu przedmiotowym interpretacji zostaje poddana organizacja - przedsiębiorstwo społeczne (ang. social entrepreneurship organization, social enterprise). Jest ono traktowane jako „pojęcie zbiorowe określające organizacje, które działają dla realizacji celów społecznych. Mogą one przyjmować różne formy prawne, jednak łączą je zasady poszukiwania rozwiązań opartych na doświadczeniach komercyjnych dla osiągnięcia celów społecznych i możliwości reinwestowania zysków z działalności z korzyścią dla społeczności [Haugh, 2010, s. 201]. Istotę tego podejścia stanowi dualna natura analizowanych podmiotów oraz konsekwencje z tym związane. Z jednej strony podmioty te przejawiają orientację rynkową, ale równocześnie są nastawione na realizację celów społecznych, co wymaga umiejętnego zarządzania, łączenia efektywności gospodarowania z realizacją misji społecznej [Weerawardena, Sullivan, Mort, 2006].

Ujęcie procesowe koncentruje się na opisie działań i procesów podejmowanych w celu wytworzenia i utrwalenia wartości społecznej. W tym przypadku analizuje się między innymi proces uwzględniający identyfikację określonego problemu społecznego i znalezienie dla niego konkretnego rozwiązania, ocenę oddziaływania społecznego, model biznesowy i trwałość przedsięwzięcia [Robinson, 2010, s. 109]. 
Według innego podejścia, we współczesnym dyskursie na ten temat przedsiębiorczości społecznej można wyróżnić dwa nurty [Perrini, 2006, s. 6-11]: 1) wąski - łączący analizowane zagadnienie $\mathrm{z}$ teorią sektora non-profit, oraz 2) szeroki - charakteryzujący je jako nowe zjawisko interdyscyplinarne. W pierwszym przypadku przedsiębiorczość społeczną postrzega się jako sposób na zmianę działalności organizacji non-profit na bardziej rynkową, skierowaną na klientów, samowystarczalną. Uogólniając można stwierdzić, iż chodzi o wykorzystanie narzędzi stosowanych w sektorze komercyjnym oraz rozwiązań rynkowych w sektorze organizacji społecznych. Podejście to ilustruje definicja G.A. Lasprogaty i M.N. Cotton: „Przedsiębiorczość społeczna to organizacje non-profit, które stosują strategie przedsiębiorcze w celu przetrwania na rynku i wywierania większego wpływu na swoją misję społeczną" [Lasprogata, Cotton, 2003, s. 69]. Z kolei w ramach szerszego ujęcia przedsiębiorczość społeczną opisuje się jako powstanie nowej i niezależnej, krańcowo interdyscyplinarnej dziedziny badań. W tym przypadku pomija się formę organizacyjną (przynależność do sektora for-profit lub non-profit), a zwraca raczej uwagę na innowacyjny pomysł, działalność w ramach wolnego rynku, nowatorski aspekt tych inicjatyw. To ujęcie obrazuje definicja J. Wei-Skillern i in. [2007], którzy przedstawili przedsiębiorczość społeczną jako działalność innowacyjną, kreującą wartość społeczną, mającą miejsce zarówno w ramach, jak i na styku sektora non-profit, prywatnego i publicznego.

W opinii innych badaczy kluczem do zrozumienia przedsiębiorczości społecznej są dwa elementy - oddziaływanie społeczne (social impact) oraz innowacje [np. Dees, 2008; Bornstein, 2004]. Misja i oddziaływanie społeczne stanowią główny aspekt działania przedsiębiorstw społecznych. Działania w zakresie przedsiębiorczości społecznej pozwalają na uzyskanie społecznie pożądanej wartości. Podstawowym kryterium wyróżniającym tę formę aktywności staje się wpływ na społeczeństwo związany z realizacją misji, nie zaś tworzenie bogactwa [Dees, 2008]. Z kolei innowacje służą generowaniu nowych sposobów rozwiązywania problemów społecznych oraz reagowaniu na pojawiające się potrzeby społeczne. Dzięki nim możliwe jest wywarcie trwałej zmiany społecznej, stanowiącej cel inicjatyw podejmowanych w ramach przedsiębiorczości społecznej [Alvord i in., 2004; Austin, Stevenson, Wei-Skillern, 2006]. Definiując przedsiębiorczość społeczną podkreśla się, iż polega ona na tworzeniu nowego rozwiązania, charakteryzowanego raczej przez innowacje, niż prostą replikację istniejących przedsiębiorstw lub praktyk. Ta nowość może mieć formę nowego podejścia (do pracy z grupą docelową, w realizacji celów statutowych organizacji itp.) lub nowego procesu. Ponadto przynajmniej niektóre z celów przedsiębiorstwa powinny być związane z tworzeniem wartości społecznej, czasami określanej jako „dobro społeczne”, a nie tworzenia dobrobytu osobistego lub akcjonariuszy [Austin, Stevenson Wei-Skillern 2006; Nicholls 2006].

Tytułem podsumowania można stwierdzić, iż przedsiębiorczość społeczna opisuje zróżnicowane działania i procesy polegające na wytwarzaniu oraz utrwalaniu wartości społecznej. Każdorazowo chodzi o działania przedsiębiorcze podejmowane na użytek społeczny, nastawione na innowacyjność i zmianę oraz uwarunkowane otoczeniem zewnętrznym [Brouard, Larivet, 2010]. Równocześnie należy zauważyć, iż rozwój badań nad przedsiębiorczością społeczną wskazuje, iż znajduje się ona we wstępnej fazie rozwoju. Fazę tę cechuje debata dotycząca stosowanej terminologii, granic pojęcia, legitymizowanych metod i problemów, jej użyteczności, jakości alternatywnych rozwiązań tworzonych w ramach nowej dziedziny wiedzy [Nicholls, 2013]. 


\section{Istota rozwoju}

Rozwój jest procesem powszechnym, naturalną cechą wszystkich obiektów stanowiących przedmiot zainteresowania człowieka [Januszkiewicz, 2011, s. 202]. Z tego względu termin ten jest wykorzystywany i definiowany na gruncie różnych nauk - od ekonomii, finansów oraz nauk o zarządzaniu [np. Chomątowski, 1986; Pierścionek, 1996; Machaczka, 1998; Wyrwicka, 2003; Hausner, 2012; Poskrobko, 2012], przez socjologię [Szczepański, 1970; Masłyk, 1985; Sztompka, 2010], psychologię [np. Tyszkowa, 1996; Brzezińska, Trempała, 2000, s. 231-283], aż po filozofię [np. Kuniński, 2007; Węgrzecki, 2011, s. 70-79].

Słownikowe definicje opisują rozwój jako „przekształcanie się organizmów żywych; proces przeobrażeń polegający na udoskonalaniu czegoś" [Wielki słownik... 2005, s. 1002-1003] czy też „proces przeobrażeń, zmian, przechodzenia do stanów lub form bardziej złożonych lub pod pewnym względem doskonalszych; przebieg, następstwo, sposób rozwijania się zdarzeń w czasie" [Uniwersalny słownik... 2003, s. 1071]. Już na podstawie leksykalnych wyjaśnień można przypuszczać, że mamy do czynienia z terminem niejednoznacznym i obszernym.

Na gruncie nauk ekonomicznych rozwój został zdefiniowany między innymi przez J. Schumpetera. Według austriackiego ekonomisty jest on „szczególnym zjawiskiem, całkowicie obcym ruchowi okrężnemu oraz tendencji do równowagi. Jest on żywiołową, nie posiadającą charakteru ciągłego zmianą drogi ruchu okrężnego, zakłóceniem równowagi, które w sposób trwały modyfikuje i wytrąca z dawnego łożyska poprzednio istniejący stan równowagi" [Schumpeter, 1960, s. 110]. Badanie i rozumienie rozwoju - według Schumpetera - utrudnia ekonomistom obowiązująca w tej nauce metodologia, nakazująca - zgodnie z zasadą ceteris paribus - koncentrować się na tym, co niezmienne i poszukiwać równowagi [Schumpeter, 2005, cyt. za: Hausner, 2012, s. 19]. Tymczasem, według J. Hausnera, rozwój ma ewolucyjną naturę, w tym sensie jest nieprzewidywalny, nielinearny, niejednolity i nierównomierny [Hausner, 2012, s. 18].

Popularne w literaturze jest ujęcie rozwoju jako procesu polegającego na dokonywaniu się zmian [Wyrwicka, 2003]. Podkreśla się jakościowy charakter owej zmiany [Machaczka, 1998, s. 14; Pierścionek, 1996, s. 11]. O ile rozwój oznacza występowanie zmian jakościowych, ocenianych pozytywnie z punktu widzenia celu, którego one dotyczą, o tyle, gdy dochodzi do zmian ilościowych, mówi się o wzroście lub degradacji [Stabryła, 1996, s. 9; Piekarz, 2012, s. 375]. Tym samym warto dokonać rozróżnienia pomiędzy rozwojem a wzrostem, równocześnie zwracając uwagę na pojemność pierwszego z przywołanych terminów. Rozwój ma charakter jakościowy, ale równocześnie ma on liczne aspekty i skutki ilościowe. Implikuje nie tyle nasilenie się określonych zjawisk, ile zmianę ich charakteru i relacji [Hausner, 2012, s. 19]. W podobnym tonie wypowiedział się T. Poskrobko [2012], wskazując na istotę terminu oraz jego ewolucję na gruncie nauk ekonomicznych. Autor uszeregował najbardziej popularne terminy dotyczące rozwoju i wzrostu, tworząc swoistą drabinę pojęciową - od historycznie najstarszych i najwęższych aż po ich współczesne, szerokie ujęcia. Klasyfikacja obejmowała odpowiednio: wzrost gospodarczy - rozwój gospodarczy - rozwój społeczno-gospodarczy - rozwój zrównoważony. Tym samym autor zwrócił uwagę, iż rozwój może zawierać w sobie inne pojęcia stanowiące jego kategorie [Poskrobko, 2012, 79-84]. Rozwój zrównoważony jest dobrą ilustracją tych rozważań, bowiem jako najszersza koncepcja holistycznego ujęcia problemów rozwoju społeczno-gospodarczego ujmuje zarówno wzrost definiowany jako powiększanie wielkości gospodarczych (tj. 
produkt krajowy brutto, konsumpcja społeczeństwa), jak i uwzględnia aspekty jakościowe dotyczące kwestii środowiskowych i społecznych.

Literatura z zakresu socjologii i filozofii zwraca uwagę na inne aspekty analizowanego terminu. Opisuje rozwój jako proces prowadzący do zmian, wskazując na charakter i kierunek tych zmian [Masłyk, 1985, s. 18]. J. Szczepański ujął rozwój w następujący sposób: „jeżeli zmiany zachodzące w danym systemie prowadzą do zróżnicowania i wzbogacenia jego elementów składowych i (lub) zachodzących między nimi stosunków - wtedy mówimy, że system ten się rozwija" [Szczepański, 1970, s. 505]. Podobnie zdefiniowali rozwój A. Podsiad i Z. Więckowski wskazując na "sekwencję zmian zachodzących w jakimś układzie według określonych praw biologicznych, psychologicznych, socjologicznych, itp. W szczególności zmiany [te - A.P.] prowadzą do zróżnicowania i zwiększenia złożoności układu" [Podsiad, Więckowski, 1983, s. 343-344]. Podobnie rozwój wyjaśniał S. Nowak, opisując go jako „zmianę kierunkową od niższych do wyższych form istnienia danego podmiotu" [Nowak, 2011, s. 259]. Propozycje te uzupełnił P. Sztompka, wskazując na cechy tak rozumianego rozwoju, tzn. „pozytywny kierunek procesu (z upływem czasu zwiększa się poziom pewnej zmiennej lub zmiennych, ze względu na które proces rozpatrujemy) oraz kierunkowa sekwencja zmian jest uruchamiana przez mechanizmy wewnętrzne (immanentne, endogenne, zamknięte $\mathrm{w}$ ramach rozważanego systemu)" [Sztompka, 2010, s. 440].

Przy okazji przedstawionych powyżej definicji należy zwrócić uwagę na źródła owych zmian. Według socjologów rozwój jest napędzany czynnikami endogennymi (wewnątrzspołecznymi, immanentnymi, czyli zamkniętymi w ramach rozważanego systemu) [Sztompka, 2010, s. 440, 453]. Odmiennie kwestię tę postrzegają filozo- fowie, którzy wskazują na rolę procesów spontanicznych lub racjonalnego projektowania [Kuniński, 2007, s. 12].

Równocześnie warto przywołać inne definicje rozwoju, akcentujące jego fazowe ujęcie. W tym duchu rozwój opisuje J. Tchórzewski, wskazując na "długotrwały proces ukierunkowanych zmian, w którym można wyróżnić narastające po sobie prawidłowo etapy zmian (fazy rozwojowe) danego obiektu, wskazujące różnicowanie się tego obiektu pod określonym względem" [Tchórzewski, 1992, s. 342]. A zatem rozwój to także „pewien ciąg zmian, które następują po sobie w pewnym porządku, doprowadzając do wyłaniania się kolejnych różniących się od siebie postaci czegoś, co istnieje. (...) Z rozwojem mamy do czynienia wówczas, gdy (...) wyłania się coś nowego przynajmniej pod pewnym względem, co pod innymi względami może przypominać dawniejszą postać bytu albo zupełnie się od niej różnić" [Węgrzecki, 2011, s. 70, 71]. K. Fabiańska i J. Rokita zdefiniowali rozwój jako „proces przebiegający w czasie, w którym kolejne następujące po sobie zmiany występują w sposób uporządkowany i utrzymują się względnie trwale" [Fabiańska, Rokita, 1986, s. 11].

Tytułem podsumowania należy zauważyć, iż przedstawione powyżej wybrane ujęcia i definicje rozwoju świadczą o jego bogactwie znaczeniowym oraz wieloaspektowości. Intencją autorki artykułu nie było wskazywanie prawidłowych ujęć terminu, co jest w zasadzie niemożliwe, lecz podkreślenie, iż analizowanie rozwoju jakiegokolwiek zagadnienia wymaga od badacza sprecyzowania zakresu i aspektów planowanej analizy w celu dostarczenia wartościowych naukowo wyników. Uogólniając, rozwój można postrzegać jako proces zmian następujący w ramach danego obiektu lub/i jako ciąg zmian (faz) następujących po sobie. Rozwój ma wymiar jakościowy, jak i swoje przejawy ilościowe. 


\section{Rozwój przedsiębiorczości społecznej jako przedmiot badań}

Pojęcie rozwoju jest wykorzystywane do przedstawienia procesów i zjawisk we wszystkich naukach, które zajmują się badaniem zjawisk zachodzących w społeczeństwie. Termin ten jest stosowany również do opisania przedsiębiorczości społecznej. Zagadnienie to może być rozumiane i analizowane na wiele sposobów. Owa różnorodność opisu może wynikać z odmiennego definiowania przedmiotu analizy, czyli przedsiębiorczości społecznej, jak i wieloznaczności samego rozwoju. Równocześnie należy wspomnieć o odmiennych celach badawczych, które mogą przyjąć autorzy. Prowadzone analizy mogą mieć charakter eksploracyjny (poznanie nowego zjawiska), opisowy (odpowiedź na pytania: co, kiedy, gdzie i jak?) oraz wyjaśniający (udzielenie odpowiedzi na pytanie, dlaczego istnieją zaobserwowane prawidłowości oraz jakie są ich konsekwencje) [Babbie, 2009, s. 106110]. Ponadto analiza może dotyczyć różnych poziomów: makro (np. Unia Europejska, kraj), mezo (sektor społeczny), mikro (organizacja, proces przedsiębiorczy), a także odnosić się do ilościowych, jak i jakościowych aspektów rozwoju.

Tytułem zilustrowania różnorodności podejść do zagadnienia rozwoju przedsiębiorczości społecznej w tabeli 1 przedstawiono syntetycznie przykłady podejmowanych w ostatnich latach za granicą badań ${ }^{4}$ Zestawienie uwzględnia wymienione elementy tj.:

\footnotetext{
4 Wybór opracowań przedstawionych w tabeli 1 stanowi efekt analizy materiałów zamieszczonych w bazach czasopism (Proquest, ScienceDirect), indeksowanych przez Google Scholar, Publish or Perish, dostępnych na stronach Komisji Europejskiej oraz w portalu ResearchGate (www.researchgate. net). Wykorzystując słowa kluczowe: social entrepreneurship, development, growth wybrano ponad 100 artykułów zawierających w swoich tytułach ww. terminy. Następnie szczegółowej analizie poddano abstrakty tych opracowań, wybierając 30 tekstów, które korespondowały z celem niniejszego artykułu. Stanowiły one bazę, z której wybrano teksty omówione w tabeli.
}

- cele badawcze,

- różne ujęcia rozwoju oraz przedsiębiorczości społecznej,

- poziom analizy,

- rodzaj prowadzonych badań (ilościowe/ jakościowe).

Tytułem uporządkowania sposobów interpretacji zagadnienia rozwoju przedsiębiorczości społecznej można wykorzystać zidentyfikowane $\mathrm{w}$ piśmiennictwie przedmiotu kierunki (aspekty) badania rozwoju. $\mathrm{Na}$ gruncie literatury z obszaru przedsiębiorczości A. McKelvie i J. Wiklund [2010] wyróżnili trzy źródła badań w tym zakresie tj.: rozwój jako rezultat (wynik) działania różnych zmiennych, efekty rozwoju, proces rozwoju (przebieg, sposób realizacji). W literaturze psychologicznej rozwój analizuje się badając czynniki, mechanizmy i efekty [Tyszkowa, 1996]. Przyjmując, iż rozwój polega na dokonywaniu się zmian, można wykorzystać ustalenia z obszaru socjologii analizującej zakres zmian zachodzących w różnych typach zbiorowości. W tym przypadku wyróżnia się: czynniki wywołujące zmiany, prawidłowości przebiegu zmian, dziedziny ulegające zmianom, mechanizmy zmian [Szczepański, 1970, s. 507-509].

Wykorzystując powyższe ustalenia oraz analizy na temat sposobów interpretacji rozwoju sformułowane w literaturze krajowej [np. Węgrzecki, 2011, s. 71 i nast.; Brzezińska, Trempała, 2000, s. 233-236; Machaczka, 1998; Glinka, 2007, s. 63-68; Pierścionek, 1996, s. 11; Januszkiewicz, 2011, s. 201-205] oraz zagranicznej [np. Achtenhagen i in., 2010; Vickers, Lyon, 2012] można wskazać potencjalne obszary/kierunki badania zagadnienia rozwoju. Uogólniając, mogą one dotyczyć takich aspektów (wymiarów) rozwoju jak: istota (przedmiot), determinanty i uwarunkowania, trajektoria, efekty. Przenosząc niniejsze ustalenia na obszar przedsiębiorczości społeczności, analizę poświęconą jej rozwojowi można prowadzić odwołując się do następujących wymiarów: 


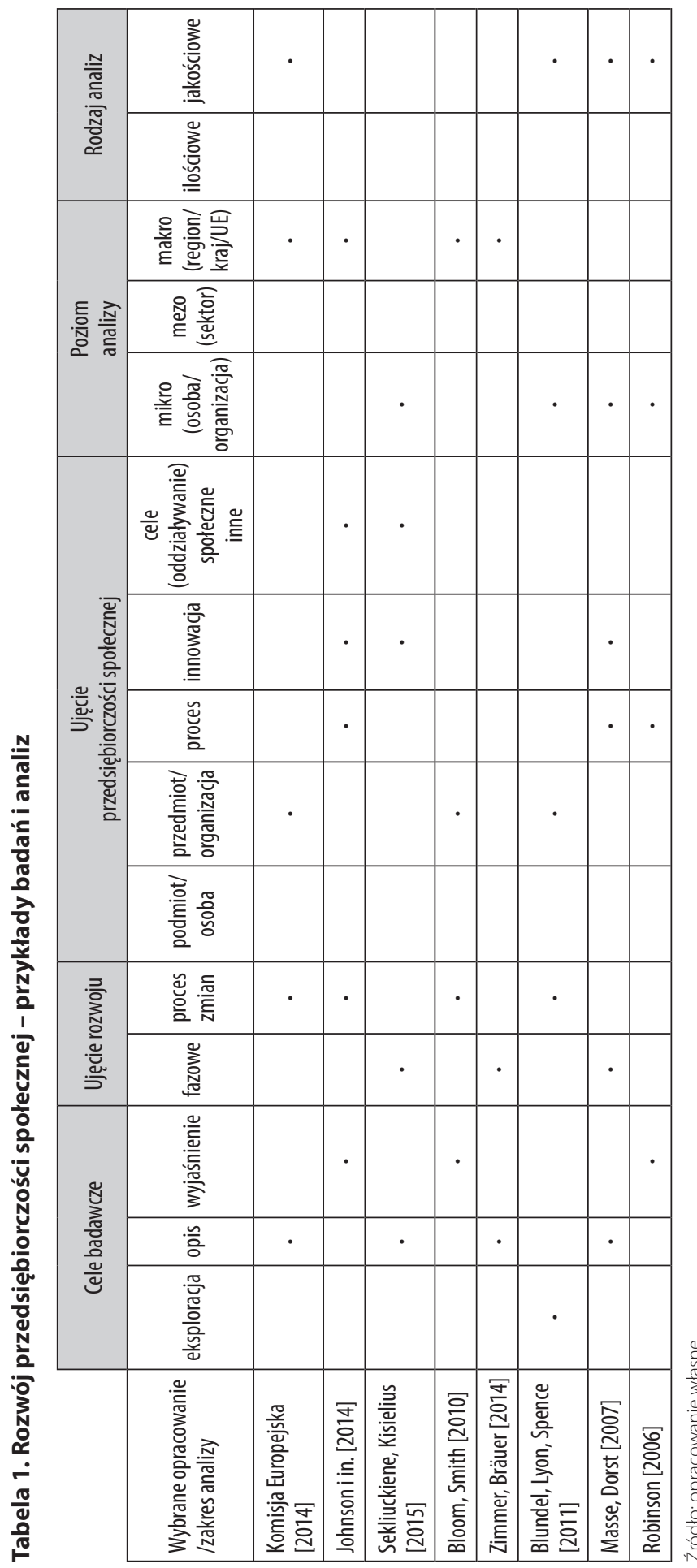


1. Istota rozwoju przedsiębiorczości społecznej.

2. Determinanty i uwarunkowania rozwoju przedsiębiorczości społecznej.

3. Trajektoria rozwoju przedsiębiorczości społecznej.

4. Efekty rozwoju przedsiębiorczości społecznej.

Ad 1. W tym przypadku można zapytać o przedmiot rozwoju, czyli kto lub co się rozwija, lub/i podlega zmianom. Nawiązując do typologii F. Perriniego [2006] oraz biorąc pod uwagę, iż analizowane zagadnienie ma swoje aspekty ilościowe, ale wiąże się również ze zmianami jakościowymi, opis przedmiotu rozwoju możne dotyczyć zmian w formie, sposobie działania, zachowaniu organizacji not for profit. Równocześnie, nawiązując do rozszerzonego ujęcia terminu przedsiębiorczości społecznej, analizę można sprofilować na sposoby rozwiązywania niepowodzeń państwa w świadczeniu usług publicznych [Aiken, 2006], metody i formy zaspokajania potrzeb społecznych i dostarczania dóbr wykorzystujące aktywność obywateli i tworzonych przez nich organizacji, sieci, partnerstw itp. działających na pograniczu państwa, społeczeństwa obywatelskiego i sektora komercyjnego [Yunus, 2008; Alvord i in., 2004].

Ad 2. Przedmiotem rozważań mogą być czynniki (wewnętrzne i zewnętrzne) oraz uwarunkowania (społeczne, kulturowe, geograficzne itp.), które inicjują, wspierają lub hamują przebieg rozwoju przedsiębiorczości o celach społecznych. Analiza może dotyczyć etapu powstawania (tworzenia) organizacji przedsiębiorczości społecznej i wówczas koncentrować się na rozpoczynaniu działalności gospodarczej nakierowanej na realizację celów społecznych. Jednocześnie może odnosić się do podmiotu działającego, wtedy przedmiotem zainteresowania będą czynniki determinujące rozwój rozumiany jako sukces organizacji [Wronka-Pośpiech, 2015; Ochinowski, 2010] lub przetrwanie organizacji i subiektywnie postrzegana popra- wa w zakresie istotnych dla organizacji ilościowych i jakościowych elementów [Glinka, 2007, s. 64].

Ad 3. Badanie przebiegu rozwoju przedsiębiorczości społecznej może koncentrować się na fazach (etapach), kamieniach milowych (punktach zwrotnych) zjawiska. Takie podejście pozwala uchwycić i opisać proces zmian, ale również szczegółowe zjawiska zachodzące na różnych jego etapach. Analiza może dotyczyć poziomu mikro - i wówczas odnosić się do cyklu życia organizacji lub procesu przedsiębiorczego. Może również odnosić się do poziomu makro, mając wymiar systemowy - i odnosić się do zmian relacji, związków zachodzących między sektorami (publicznym, prywatnym i obywatelskim), ich wzajemnych oddziaływań, przeobrażeń itp.

Ad 4. Analiza może koncentrować się na rezultatach osiąganych $w$ ramach inicjatyw przedsiębiorczości społecznej. Uwzględniając ich specyfikę - społeczne i ekonomiczne cele działania - efekty rozwoju będą ujmowały łącznie wartość społeczną i ekonomiczną. Wykorzystując koncepcję double bottom line lub koncepcję wartości mieszanej (blended value) można analizować wielowymiarowe korzyści generowane przez inicjatywy w obszarze przedsiębiorczości społecznej.

Wymiary analizy rozwoju przedsiębiorczości społecznej oraz odpowiadające im pytania badawcze przedstawiono w tabeli 2 .

Biorąc pod uwagę nowatorski charakter zagadnienia przedsiębiorczości społecznej, wszystkie wymienione powyżej aspekty stanowią interesujący i ważny obszar potencjalnych analiz. Omówione ujęcia tematu są obecne w polskiej literaturze przedmiotu, czego dowodem jest lista wybranych krajowych opracowań w tym zakresie przedstawiona w tabeli 2. Świadczą one o tym, iż zagadnienie przedsiębiorczości społecznej zyskuje na znaczeniu w środowisku akademickim. Jednocześnie, szersze podjęcie tematu przez akademików w kraju pozwoliłoby lepiej zrozumieć zjawisko, poznać jego reguły 
Tabela 2. Potencjalne kierunki badań rozwoju przedsiębiorczości społecznej

\begin{tabular}{|c|c|c|}
\hline Obszar analizy & Pytania badawcze & $\begin{array}{l}\text { Przykładowe artykuły } \\
\text { w literaturze krajowej }\end{array}$ \\
\hline Istota (przedmiot) rozwoju & $\begin{array}{l}\text { Czym jest przedsiębiorczość społeczna? } \\
\text { Jakie są cechy przedsiębiorstwa społecznego? } \\
\text { Jaka jest rola przedsiębiorcy społecznego? }\end{array}$ & \begin{tabular}{|l|} 
Zboroń [2015]; Praszkier, Nowak [2015]; \\
Starnawska [2015]; Żur [2014]; Pankiv, \\
Duranowski [2014]; Klich [2013]; Frączek, Hausner, \\
Mazur [2012]; Lech [2012]; Leś [2008]
\end{tabular} \\
\hline $\begin{array}{l}\text { Czynniki } \\
\text { i uwarunkowania rozwoju }\end{array}$ & $\begin{array}{l}\text { Jakie czynniki i uwarunkowania determinują } \\
\text { powstawanie inicjatyw (organizacji) } \\
\text { przedsiębiorczości społecznej? } \\
\text { Jakie czynniki wpływają na proces przedsiębiorczy? }\end{array}$ & $\begin{array}{l}\text { Paczyński i in. [2014]; Bogacz-Wojtanowska i in. } \\
\text { [2013]; Wronka-Pośpiech [2015]; Ochinowski } \\
\text { [2010]; Laurisz, Mazur [2008]; Kraśnicka, Wronka } \\
\text { [2010]; Starnawska [2014]; Kaźmierczak, Rymsza } \\
\text { [2007] }\end{array}$ \\
\hline Trajektoria rozwoju & $\begin{array}{l}\text { Jak przebiega proces przedsiębiorczy } \\
\text { w inicjatywach (organizacjach) przedsiębiorczości } \\
\text { społecznej? } \\
\text { Jakie są etapy rozwoju przedsiębiorczości } \\
\text { społecznej w Polsce? }\end{array}$ & $\begin{array}{l}\text { Ciepielewska-Kowalik i in. [2015]; Praszkier i in. } \\
\text { [2014] }\end{array}$ \\
\hline Efekty rozwoju & $\begin{array}{l}\text { Jakie rezultaty generują inicjatywy } \\
\text { przedsiębiorczości społecznej? } \\
\text { Jak mierzyć oddziaływanie przedsiębiorstw } \\
\text { społecznych? } \\
\text { Jak zwiększać oddziaływanie społeczne } \\
\text { przedsiębiorstw społecznych? }\end{array}$ & $\begin{array}{l}\text { Poławski, Zalewski [2015]; Głowacki, Jelonek } \\
\text { [2013]; Frączek i in. [2010] }\end{array}$ \\
\hline
\end{tabular}

Źródło: opracowanie własne.

i prawidłowości. Wyniki owych analiz mogłyby być użyteczne do planowania, zarządzania oraz wspierania inicjatyw tego typu zarówno z perspektywy państwa (polityk publicznych), jak i osób zarządzających przedsięwzięciami tego typu (celem doskonalenia sprawności ich działania, procesu zarządzania).

\section{Podsumowanie}

W artykule podjęto próbę usystematyzowania wiedzy na temat sposobów badania rozwoju przedsiębiorczości społecznej. Przedmiotem omówienia były dwa zakresowo nieostre i treściowo wieloznaczne terminy. W przypadku przedsiębiorczości społecznej mamy do czynienia z młodą, rozwijającą się dziedziną badań, w trakcie procesu samookreślenia [Cho, 2010, s. 47-69], która wymaga między innymi uspójnienia bazy pojęciowej, wypracowania powszechnie akceptowanej definicji terminu, a także ugrun- towania teoretycznego oraz empirycznego. Istnieje zatem duży potencjał do badań i analiz w tym obszarze, również tych dotyczących rozwoju.

Z kolei w przypadku rozwoju mamy do czynienia z kategorią „na usługach wszystkich dziedzin życia i działalności poznawczej" [Borys, 2005, s. 85], zakorzenioną w tradycji badań społecznych oraz debacie publicznej. Niemniej jednak warto pamiętać, iż wykorzystanie tego terminu wymaga od badacza sprecyzowania obszarów (aspektów) planowanej analizy w celu dostarczenia wartościowych naukowo wyników.

Zestawienie wspomnianych dwóch terminów stanowiło przedmiot rozważań podjętych w ramach artykułu. Nawiązując do wypracowanych w literaturze przedmiotu sposobów badania rozwoju przedstawiono wybrane aspekty analizy tak opisanego zagadnienia. Potencjalne kierunki analizy rozwoju przedsiębiorczości społecznej mogą do- 
tyczyć jej przedmiotu, uwarunkowań, procesu i wyników. Podjęte dotychczas w kraju prace badawcze świadczą o wzroście zainteresowania i uznania dla niniejszego zagadnienia.

\section{Literatura}

Achtenhagen L., Naldi L., Melin L. (2010). „Business Growth - Do Practitioners and Scholars Really Talk About the Same Thing?", Entrepreneurship Theory and Practice, Special Issue: Entrepreneurial and Business Growth, vol. 34, iss. 2.

Alvord S.H., Brown L.D., Letts C.W. (2004). „Social Entrepreneurship and Societal Transformation. An Exploratory Study", Journal of Applied Behavioral Science, vol. 40, no. 3.

Austin J., Stevenson H., Wei-Skillern J. (2006). ., Social and Commercial Entrepreneurship: Same, Different, or Both?", Entrepreneurship Theory and Practice, vol. 30, iss. 1.

Babbie E. (2009), Badania społeczne w praktyce. Warszawa: Wydawnictwo Naukowe PWN.

Bacq S., Janssen F. (2011). "The multiple face of social entrepreneurship: A review of definitional issues based on geographical and thematic criteria", Entrepreneurship \& Regional Development, vol. 23, no. 5-6. Bloom P.N., Smith B.R. (2010). .I Identifying the Drivers of Social Entrepreneurial Impact: Theoretical Development and an Explanatory Empirical Test of SCALERS", Journal of Social Entrepreneurship, vol. 1, no. 1.

Blundel R., Lyon F., Spence L.J. (2011). Analyzing the growth process in social enterprises: an historical perspective, 3rd EMES International Research Conference on Social Enterprise: Social Innovation through Social Entrepreneurship in Civil Society: EMES Selected Papers Series, 4-7 July 2011, Roskilde, Denmark, http://citeseerx.ist.psu.edu/viewdoc/do wnload?doi=10.1 1.371.5568\&rep=rep $1 \&$ type $=p d f$ (dostęp: 28.12.2015).

Bornstein D. (2004). How to change the world. Social entrepreneurs and the Power of New Ideas. Oxford: Oxford University Press.

Borys T. (2005). "Aksjologiczne podstawy rozwoju”, w: F. Pionek, B.J. Czerny (red.), Humanistyczne, ekonomiczne i ekologiczne aspekty kategorii "rozwój”. Polska Akademia Nauk, Komitet przy Prezydium PAN "Człowiek i Środowisko", Zeszyty Naukowe 40, Warszawa-Bytom.

Brock D.D., Kim M. (2011). Social Entrepreneurship Education Resource Handbook. Ashoka U, http:// ashokau.org/wp-content/uploads/2011/04/AshokaU_Handbook_Preview.pdf (dostep: 10.12.2015).

Brouard F., Larivet S. (2010). „Essay of clarifications and definitions of related concepts of social enterprise, social entrepreneur and social entrepreneurship", w: A. Fayolle, H. Matlay (red.), Handbook
Jednocześnie zauważyć należy duży potencjał dla prac o charakterze empirycznym i teoretycznym, z wykorzystaniem dorobku nauk ekonomicznych, społecznych i prawnych.

of Research on Social Entrepreneurship. Cheltenham, Northampton: Edward Elgar Publishing.

Brzezińska A., Trempała J. (2000). „Wprowadzenie do psychologii rozwoju", w: J. Strelau (red.), Psychologia. Podręcznik akademicki, Tom I. Gdańsk: Gdańskie Wydawnictwo Psychologiczne.

Cho A.H. (2010). „Polityka, wartości i przedsiębiorczość społeczna - analiza krytyczna", w: J. Mair, J. Robinson, K. Hockerts (red.), Przedsiębiorczość społeczna. Warszawa: Wydawnictwo Wyższej Szkoły Pedagogicznej TWP w Warszawie.

Chomątowski S. (1986). Rozwój przemysłu na świecie. Kraków: Akademia Ekonomiczna w Krakowie.

Ciepielewska-Kowalik A., Pieliński B., Starnawska M., Szymańska A. (2015). „Social Enterprise in Poland: Institutional and Historical Context", ICSEM Working Papers, no. 11. Liege: The International Comparative Social Enterprise Models Project.

Dacin P.A., Dacin M.T., Matear M. (2010). „Social Entrepreneurship: Why We Don't Need a New Theory and How We Move Forward From Here", Academy of Management Perspectives, vol. 24, no. 3.

Dees J.G. (2008). „Definicja przedsiębiorczości społecznej", w: J.J. Wygnański (red.), Przedsiębiorstwo społeczne. Antologia kluczowych tekstów. Warszawa: Fundacja Inicjatyw Społeczno-Ekonomicznych.

Fabiańska K., Rokita J. (1986). Planowanie rozwoju przedsiębiorstwa. Warszawa: Państwowe Wydawnictwo Ekonomiczne.

Frączek M., Krupnik S., Osiborska K., Pacut A., Szczucka A. (2010). Monitoring przedsiębiorstw społecznych w Małopolsce. Raport z badań. Kraków: Centrum Ewaluacji i Analiz Polityk Publicznych UJ, Fundacja Gospodarki i Administracji Publicznej.

Frączek M., Hausner J., Mazur S. (2012). Wokół ekonomii społecznej. Kraków: MSAP UEK.

Głąbicka K. (2011).,"Gospodarka społeczna w dokumentach Unii Europejskiej", w: M. Grewiński, M. Rymsza (red.), Polityka aktywizacji w Polsce. Usługi reintegracji w sektorze gospodarki społecznej. Warszawa: Wyższa Szkoła Pedagogiczna w TWP w Warszawie.

Glinka B. (2007). „Kulturowe wyznaczniki rozwoju organizacji", w: K.T. Konecki, P. Chomczyński (red.), Zarzqdzanie organizacjami. Organizacja jako proces. Łódż: Wydawnictwo Uniwersytetu Łódzkiego.

Głowacki J., Jelonek M. (2013). Mierzenie społecznej wartości dodanej podmiotów ekonomii społecznej. Kraków: MSAP UEK.

Granados M.L., Hlupic V., Coakes E., Mohamed S. (2011)..,Social enterprise and social entrepreneurship research and theory: A bibliometric analysis from 1991 to 2010". Social Enterprise Journal, vol. 7(3). 
Haugh H. (2010). „Przedsiębiorstwo społeczne: więcej niż wynik ekonomiczny i indywidualny zysk", w: J. Mair, J. Robinson, K. Hockerts (red.), Przedsiębiorczość społeczna. Warszawa: Wydawnictwo Wyższej Szkoły Pedagogicznej TWP w Warszawie.

Hausner J. (2012). „Koncepcje modelu polityki rozwoju społeczno-gospodarczego", w: J. Górniak, S. Mazur (red.), Zarzązanie strategiczne rozwojem. Warszawa: Ministerstwo Rozwoju Regionalnego.

Hill T.L., Kothari T.H., Shea M. (2010). „Patterns of Meaning in the Social Intrepreneurship Entrepreneurship Literature: A Research Platform", Journal of Social Entrepreneurship, vol. 1, no. 1.

Hockerts K. (2010). "Źródła możliwości powstania i działania przedsiębiorstw komercyjnych o celach społecznych", w: J. Mari, J. Robinson, K. Hockerts (red.), Przedsiębiorczość społeczna. Warszawa: Wydawnictwo Wyższej Szkoły Pedagogicznej TWP w Warszawie.

Hoogendoorn B., Pennings E., Thurik R. (2010). „What Do We Know About Social Entrepreneurship: An Analysis of Empirical Research", International Review of Entrepreneurship, vol. 8, iss. 2.

Januszkiewicz K. (2011). „Rozważania na temat rozwoju - Rys teoretyczny", w: J. Czekaj, M. Lisiński (red.), Rozwój koncepcji i metod zarzadzania. Kraków: Uniwersytet Ekonomiczny w Krakowie, Fundacja Uniwersytetu Ekonomicznego w Krakowie.

Kaźmierczak T., Rymsza M. (red.), (2007). Kapitał społeczny. Ekonomia społeczna. Warszawa: Instytut Spraw Publicznych.

Klich J. (2013).,Przedsiębiorczość i społeczna przedsiębiorczość jako przedmiot badań", Ekonomia Społeczna, nr 1(6).

Komisja Europejska (2014). A map of social enterprises and their eco - systems in Europe: Executive Summary. Komisja Europejska, http://ec.europa.eu/ DocsRoom/documents/7561/attachments/1/translations/en/renditions/pdf (dostęp: 10.12.2015).

Kraśnicka T. (2002). Koncepcja rozwoju przedsiębiorczości ekonomicznej i pozaekonomicznej. Katowice: Wydawnictwo Uczelniane Akademii Ekonomicznej im. K. Adamieckiego w Katowicach.

Kraśnicka T., Wronka M. (2010). „Istota i uwarunkowania przedsiębiorczości społecznej”, w: K. Jaremczuk (red.), Uwarunkowania przedsiębiorczości. Różnorodność i jedność. Tom I. Tarnobrzeg: Państwowa Wyższa Szkoła Zawodowa im. prof. Stanisława Tarnowskiego w Tarnobrzegu.

Kuniński M. (2007). „Rozważania o rozwoju”, w: Wokół społecznej przedsiębiorczości, Kraków: Małopolska Agencja Rozwoju Regionalnego S.A.

Lasprogata G.A., Cotton M.N. (2003). „Contemplating enterprise: the business and legal challenges of social entrepreneurship", American Business Law Journal, no. 41.

Laurisz N., Mazur S. (2008). „Kluczowe czynniki rozwoju przedsiębiorczości społecznej", w: J. Hausner, A. Giza-Poleszczuk (red.), Ekonomia społeczna w Pol- sce: osiagnięcia, bariery rozwoju i potencjał w świetle wyników badań. Warszawa: Fundacja Inicjatyw Społeczno-Ekonomicznych.

Lech K. (2012). „Przedsiębiorczość społeczna: prolegomena: termin i definicje zjawiska", Zarządzanie Zmianami, nr 3-4.

Leś E. (red.), (2008). Gospodarka społeczna i przedsiębiorstwo społeczne. Wprowadzenie do problematyki. Warszawa: Wydawnictwa Uniwersytetu Warszawskiego.

Lumpkin G.T., Katz J.A. (red.), (2011). "Social and sustainable entrepreneurship", Advances in Entrepreneurship, Firm Emergence and Growth, vol. 13.

Machaczka J. (1998). Zarządzanie rozwojem organizacji. Czynniki, modele, strategia, diagnoza. Warszawa-Kraków: Wydawnictwo Naukowe PWN.

Mair J., Robinson J., Hockerts K. (red.), (2006). Social Entrepreneurship. New York: Palgrave Macmillan.

Masłyk E. (1985). Zmiana i niepewność w procesach organizacyjnych, Warszawa: Państwowe Wydawnictwo Naukowe.

Masse S.J., Dorst K. (2007). Exploring the development process of grassroots social entrepreneurship, Center for Corporate Values and Responsibility, https://opus.lib.uts.edu.au/handle/10453/7337 (dostęp: 12.12.2015).

McKelvie A., Wiklund J. (2010). "Advancing Firm Growth Research: A Focus on Growth Mode Instead of Growth Rate", Entrepreneurship Theory and Practice, vol. 34, iss. 2.

Nicholls A. (red.), (2006). Social Entrepreneurship. New Models of Sustainable Change. Oxford: Oxford University Press.

Nowak S. (2009). „Modele zmiany kierunkowej a ludzkie wartości: Teoria postępu jako stosowana nauka społeczna", w: P. Sztompka, M. Kucia (red.), Socjologia. Lektury. Kraków: Wydawnictwo Znak.

Nowak S. (2011). Metodologia badań społecznych. Warszawa: Wydawnictwo Naukowe PWN.

Ochinowski T. (2010). Czynniki ekonomicznego sukcesu przedsiębiorstwa społecznego. Raport z badań. Warszawa: Fundacja Archidiecezji Warszawskiej Pomocy Bezrobotnym i Biednym NADZIEJA, http:// www.fundacja-nadzieja.org.pl/es/pdf/ochinowski_ artykul.pdf (10.12.2015).

OECD (1999). Social enterprises. Paris: OECD.

Orhei L. (2011). The competence of social entrepreneurship. A multidimesional competence approach, HAN Business Publication, http://han.surfsharekit. nl:8080/get/smpid:15376/DS2 (dostęp: 10.12.2015).

Paczyński W., Pacut A., Potkańska D. (2014). A map of social enterprises and their eco-systems in Europe. Country Report: Poland. European Commission, http://ec.europa.eu/social/keyDocuments.jsp?advS earchKey=socentcntryrepts\&mode $=$ advancedSub mit\&langl\&langld=en (dostęp: 25.05.2015).

Pankiv O., Duranowski W. (red.) (2014). Przedsiębiorczość społeczna a praca socjalna, Warszawa: Centrum Rozwoju Zasobów Ludzkich. 
Perrini F. (2006). "Social entrepreneurship domain: setting boundaries", w: F. Perrini (red.), The New Social Entrepreneurship. What Awaits Social Entrepreneurial Ventures? Cheltenham, Northampton: Edward Elgar Publishing.

Piekarz H. (2012). „Rozwój i zarządzanie zmianami”, w: A. Stabryła (red.), Podstawy organizacji i zarzadzania. Podejście i koncepcje badawcze. Kraków: Uniwersytet Ekonomiczny w Krakowie.

Pierścionek Z. (1996). Strategie rozwoju firmy. Warszawa: Wydawnictwo Naukowe PWN.

Podsiad A., Więckowski Z. (1983). Mały słownik terminów i pojęć filozoficznych dla studiujących filozofię chrześcijańskq. Warszawa: Instytut Wydawniczy Pax.

Poławski P., Zalewski D. (red.), (2015). Efektywna i skuteczna przedsiębiorczość społeczna: kalkulator kondycji podmiotów ekonomii społecznej. Podręcznik. Warszawa: Instytut Pracy i Spraw Socjalnych, Katowice: Regionalny Ośrodek Polityki Społecznej Województwa Śląskiego.

Poskrobko T. (2012). „Nowe koncepcje i teorie rozwoju w ekonomii", w: S. Czaja, A. Becla, J. Włodarczyk, T. Poskrobko (red.), Wyzwania współczesnej ekonomii. Wybrane problemy. Warszawa: Wydawnictwo Difin.

Praszkier R., Nowak A. (2015). Przedsiębiorczość społeczna: teoria i praktyka, wydanie 2. Warszawa: Wolters Kluwer Polska.

Praszkier R., Zabłocka-Bursa A., Józwik E. (2014). Social Enterprise, Social Innovation and Social Entrepreneurship in Poland: A National Report, http:// www.fp7-efeseiis.eu/national-report-poland/ (dostęp: 15.04.2015).

Robinson J. (2006). „Navigating Social and Institutional Barriers to Markets: How Social Entrepreneurs Identify and Evaluate Opportunities", w: J. Mair, J. Robinson, K. Hockerts (red.), Social Entrepreneurship. New York: Palgrave Macmillan.

Sassmannshausen S.P., Volkmann Ch. (2013). „A Bibliometric Based http://elpub.bib.uni-wuppertal.de/ edocs/dokumente/fbb/wirtschaftswissenschaft/sdp/ sdp13/sdp13003.pdf (dostęp: 10.12.2015).

Schumpeter J. (1960). Teoria rozwoju gospodarczego. Warszawa: Państwowe Wydawnictwo Naukowe.

Schumpeter J.A. (2005). "Development", Journal of Economic Literature, vol. XLIII.

Sekliuckiene J., Kisielius E. (2015). „Development of Social Entrepreneurship Initiatives: A Theoretical Framework", Procedia - Social and Behavioral Sciences, 213.

Johnson T., Barco S., Daniele D., Lublińska D., Spear R., (2014). Policy meets practice - enabling the growth of social enterprises. Warszawa: Ministerstwo Rozwoju, http://www.socialeconomy.pl/sites/ default/files/files/Social\%20Entrepreneurship\%20 Network_final_Publication\%281\%29.pdf (dostęp: 04.12.2015)

Shockley G.E., Frank P.M., Stough R.R. (red.), (2008). Non-market entrepreneurship: Interdisciplina- ry Approaches. Cheltenham, Northampton: Edward Elgar Publishing.

Starnawska, M. (2014). Zachowanie poprzez sieciowanie w przedsiębiorczości społecznej w odpowiedzi na trudne otoczenie instytucjonalne - przypadek 5 spółdzielni socjalnych, Problemy Zarządzania, vol. 12, $\mathrm{nr} 4$ (49), t. 2.

Starnawska M. (2015). „Analiza dobrych praktyk ekonomii społecznej w Polsce - o zasobach i ich pozyskiwaniu w przedsiębiorczości społecznej", Studia i Materiały, nr 2, Wydział Zarządzania, Uniwersytet Warszawski.

Szczepański J. (1970). Elementarne pojęcia socjologii. Warszawa: Państwowe Wydawnictwo Naukowe.

Sztompka P. (2010). Socjologia. Analiza społeczeństwa. Kraków: Wydawnictwo Znak.

Tchórzewski J. (1992). Cybernetyka życia i rozwoju systemów. Siedlce: Wyższa Szkoła Rolniczo-Pedagogiczna w Siedlcach.

Tyszkowa M. (1996). „Pojęcie rozwoju i zmiany rozwojowej", w: M. Przetacznik-Gierowska, M. Tyszkowa (red.), Psychologia rozwoju człowieka. Zagadnienia ogólne. Warszawa: Wydawnictwo Naukowe PWN.

Uniwersalny słownik języka polskiego (2003). Tom III. S. Dubisz (red.). Warszawa: Wydawnictwo Naukowe PWN.

Vickers I., Lyon F. (2012). "Beyond green niches? Growth strategies of environmentally-motivated social enterprises", International Small Business Journal, vol. 32, iss. 4.

Weerawardena J., Mort G.S. (2006). „Investigating social entrepreneurship: a multidimensional model", Journal of World Business, vol. 4.

Węgrzecki A. (2011). Zarys filozofii. Kraków: Wydawnictwo Uniwersytetu Ekonomicznego w Krakowie.

Wielki słownik poprawnej polszczyzny PWN (2005). A. Markowski (red.). Warszawa: Wydawnictwo Naukowe PWN.

Wronka-Pośpiech M. (2015).,Identyfikacja zależności pomiędzy orientacją przedsiębiorczą a sukcesem przedsiębiorstw społecznych - wyniki badań empirycznych", Zeszyty Naukowe Politechniki Śląskiej, nr 1.

Wyrwicka M.K. (2003).,Endogenne przesłanki organizacyjne rozwoju przedsiębiorstwa", Rozprawy, nr 34, Poznań: Wydawnictwo Politechniki Poznańskiej.

Zboroń H. (2015). „Ekonomia społeczna a ekonomia rynku - alternatywa czy dopełnienie?", Studia Oeconomica Posnaniensia, vol. 3, nr 7.

Zimmer A., Bräuer S. (2014). The Development of Social Entrepreneurs in Germany. Münster: Institut für Politikwissenschaften, https://www.uni-muenster.de/imperia/md/content/ifpol/mitarbeiter/zimmer/developement_of_social_entrepreneurs.pdf.

Żur A. (2014). „Korzyści, bariery i perspektywy rozwoju przedsiębiorczości społecznej w Polsce", w: K. Zieliński (red.), Formy i przejawy współczesnej przedsiębiorczości w Polsce, Warszawa: Difin. 


\section{The development of social entrepreneurship: the essence and trends analysis}

Summary: Background: The subject of discussion in the article is the issue of the development of social entrepreneurship. It consists of two range-of-focus in terms of content and ambiguous terms. On the one hand, social entrepreneurship is a young, growing area of research that arouse international interest in various circles of the late twentieth century. On the other hand, development is a category rooted in the tradition of social research and public debate.

Objectives: The aim of this article is to systematize the knowledge about the importance of both the above-mentioned concepts and presentation of selected methods of analysis of the issues described as the development of social entrepreneurship.

Methods: The critical analysis of literature devoted to the study of social entrepreneurship and development.

Results: In the light of the literature analysis of the development of social entrepreneurship may relate to the subject, conditions, process and results.

Conclusions: Research taken so far in the country shows an increase of interest in and appreciation of this issue. At the same time, the obvious conclusion about the need to develop in Poland, in the indicated areas of work of the empirical and theoretical achievements with the use of economic, social and legal science.

Keywords: social entrepreneurship, development, subject and scope of the analysis.

\section{Prawa autorskie i licencja / Copyright and License}

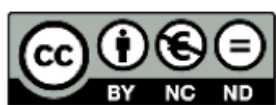

BY NC ND
Artykuł opublikowano na licencji Creative Commons

Uznanie autorstwa - Użycie niekomercyjne - Bez utworów zależnych 3.0 Polska http://creativecommons.org/licenses/by-nc-nd/3.0/pl/

This article is published under the terms of the Creative Commons Attribution - NonCommercial - NoDerivs (CC BY-NC-ND 3.0) License

http://creativecommons.org/licenses/by-nc-nd/3.0/ 